\title{
CZY WOLNO SIĘ ŚMIAĆ NA WOJNIE? WOKÓł WARSZAWSKIEJ KARIERY TEATRU „DRUGIEGO NURTU” W LATACH 1914-1918 (OCZAMI WYBRANYCH SATYRYKÓW I KRYTYKÓW LITERACKICH)
}

JoANNA NiEWIAROWSKa

\author{
Wydział Nauk Humanistycznych UKSW \\ Department of Humanities, \\ Cardinal Stefan Wyszyński University in Warsaw \\ j.niewiarowska@uksw.edu.pl \\ ORCID: 0000-0002-9365-1560
}

W 1913 roku Andrzej Strug opatrzył swoją satyryczną powieść-burleskę Zakopanoptikon mottem w formie pytania: „Czy wolno dziś Polakowi się śmiać"? Ryszard Nycz, pisząc o przemianach modernistycznych w Polsce, dokonujących się według badacza mniej więcej od 1910 roku, uznał powieść Struga i postawione przez niego pytanie za symbol nowej postawy i wrażliwości polskich pisarzy ${ }^{2}$. Uruchomienie bowiem przez Struga żywiołu środków komicznych - elementów farsy, burleski, parodii, pastiszu, groteski - wiązało się zdaniem Nycza z ogólną tendencją schyłkowego etapu Młodej Polski do demistyfikacji, walki z tym, co dotąd uchodziło za sztywne, konwencjonalne, mechaniczne w zachowaniu i funkcjonowaniu świata. „Gesty śmiechu”, jak je nazywa Nycz, weszły do repertuaru nowoczesnych środków wyrazu, pozwalających na obnażanie obowiązujących schematów kulturowych i estetycznych. Demistyfikacja ta była konieczna, by mogło

1 A. Strug, Zakopanoptikon, czyli kronika czterdziestu dziewięciu dni deszczowych w Zakopanem, Warszawa 1957, s. 183-184; pierwodruk: „Wiek Nowy” 1913-1914.

2 R. Nycz, Gest śmiechu. Z przemian świadomości literackiej początku XX wieku (do pierwszej wojny światowej), [w:] idem, Język modernizmu. Prolegomena historycznoliterackie, Toruń 2013, s. 249 i n. 
dojść do wcielenia w życie nowych modeli światopoglądowych - między innymi witalizmu, aktywizmu, afirmacji życia, codzienności i zmienności egzystencji. Komizm był w tym ujęciu jedną ze strategii artystycznych, które posiadały szczególnie efektywny potencjał kontrkulturowy i sprawczy, stanowił więc ważny składnik nowoczesności krytycznej3.

„Gesty śmiechu” były jednak w polskiej kulturze pierwszej połowy XX wieku nie tylko narzędziem społecznej i kulturowej zmiany, ale też częścią przemian cywilizacyjnych, które przyczyniły się do powstania oraz rozwoju kultury masowej i popularnej. Procesy te były już przez badaczy opisywane tak w odniesieniu do Młodej Polski, jak i (zwłaszcza) dwudziestolecia międzywojennego ${ }^{4}$.

Na tym tle wiedza o fenomenie „krotochwilizmu” i „rozmirażowania” Polaków w latach pierwszej wojny światowej - jak ironicznie nazywali „apetyty” warszawskiej publiczności niektórzy ówcześni krytycy - jest bardzo niewielka ${ }^{6}$. Fenomen rozwoju w tym okresie „małych form” - zgod-

3 Zob. M.P. Markowski, Polska literatura nowoczesna. Leśmian - SchulzWitkacy, Kraków 2007, s. 54-60.

4 W perspektywie historycznoliterackiej zob. R. Nycz, op. cit.; M. Urbanowski, Gest śmiechu w literaturze dwudziestolecia międzywojennego (rekonesans), „Wielogłos” 2007, nr 1, s. 119-129; w perspektywie socjologiczno-kulturowej: S. Żółkiewski, Kultura literacka (1918-1932), Wrocław 1973, s. 329-332.

5 Chodzi o artykuły Władysława Rabskiego i Adolfa Nowaczyńskiego, o których będzie mowa w dalszej części pracy.

${ }^{6} \mathrm{Na}$ temat kabaretu i instytucji pokrewnych najwięcej informacji znajdziemy w pracach syntetycznych Doroty Fox, Izoldy Kiec i Dobrochny Ratajczakowej, dotyczących rozwoju tych scen po 1918 roku, niekiedy również w opracowaniach kabaretianów poszczególnych twórców, np. Juliana Tuwima, oraz w syntezach historyczno-teatralnych schyłku Młodej Polski (M.O. Bieńka, Prowizorium wojenne, [w:] eadem, Teatr warszawski 1880-1919, Warszawa 2015, s. 243-251; R. Taborski, Warszawskie teatry prywatne w okresie Młodej Polski. 1905-1918, Warszawa 1980, s. 175-199; E. Krasiński, Warszawskie sceny 1918-1939, Warszawa 1976, s. 10-14.) Ciekawy obraz życia teatralno-kabaretowego tego okresu wyłania się z literatury dokumentu osobistego, przede wszystkim wspomnieniowej: Kazimierza Wroczyńskiego, Jana Brzechwy, Ludwika Sempolińskiego czy Andrzeja Pronaszki. O ile w przypadku teatru oficjalnego nurtu oraz literatury satyrycznej (np. felietony Perzyńskiego w wysokonakładowych periodykach, powiększające się nakłady pism 
nie z określeniem jednego z protoplastów polskiego kabaretu, Kazimierza Wroczyńskiego 7 - czy teatru „drugiego nurtu” - według ujęcia Zbigniewa Raszewskiego $^{8}$ - jest interesujący jako istotna część ogólnej tendencji modernizacyjnej polskiej kultury, pozwalająca lepiej zrozumieć jej nowoczesną odmianę, rozmaite aporie i związane z nimi lęki, oraz odzyskać ciągłość zachodzących w pierwszej połowie XX wieku przemian. Między „gestami śmiechu" młodopolan, opisanymi przez Nycza, a ich późniejszymi kontynuatorami, scharakteryzowanymi przez Macieja Urbanowskiego, nie ma kilkuletniej kulturowej próżni - a takie wrażenie czasami można odnieść, czytając prace historyków literatury obejmujące okres pierwszej wojny światowej.

To w latach 1914-1918 w Warszawie na masową skalę zaczęły się rozwijać instytucje i praktyki artystyczne posługujące się komizmem. Wtedy też zawiązana została nowoczesna „wspólnota śmiechu”, która gesty forpoczt polskiego modernizmu (m.in. Bolesława Leśmiana ${ }^{10}$, Romana Jaworskiego, Andrzeja Struga, Witkacego oraz wciąż jeszcze elitarnych środowisk

satyrycznych: „Sowizdrzała” i „Muchy”) niewyczerpanym źródłem wiedzy jest prasa, o tyle teatr „drugiego nurtu” jest w tym obiegu informacji niemal nieobecny przedstawienia nie były sprawozdawane ani recenzowane, a jedynie anonsowane lub reklamowane. Teksty powstające na ich potrzeby przetrwały w niewielkim ułamku, najczęściej w postaci piosenek, które weszły do społecznego obiegu pozateatralnego, czasem jako utwory satyryczne publikowane w prasie, najrzadziej w przypadku form najbardziej widowiskowych. Dlatego zgromadzenie wiedzy na ten temat i rekonstrukcja o charakterze faktograficznym nastręcza wiele trudności.

7 K. Wroczyński, Kabaret, [w:] Dymek z papierosa, czyli wspomnienia o scenach, scenkach i nadscenkach, red. K. Rudzki, Warszawa 1959, s. 194.

8 Z. Raszewski, Krótka historia teatru polskiego, Warszawa 1990, s. 197.

9 Kazimierz Żygulski definiuje wspólnotę śmiechu w kategoriach socjologicznych jako typ więzi społecznej, w której śmiech i wesołość są identyfikatorami obyczajowości i poglądów oraz obowiązującego w obrębie danej grupy paradygmatu moralno-obyczajowego. Śmiech cementuje wspólnotę między nadawcami a odbiorcami dzięki świadomości wzajemnego zrozumienia; K. Żygulski, Wspólnota śmiechu. Studium socjologiczne komizmu, Warszawa 1985, s. 19.

${ }^{10}$ Leśmian w czasie wojny, w 1915 i 1916 roku, publikował na łamach poważnego opiniotwórczego miesięcznika „Myśl Polska” arcyciekawe z punktu widzenia przemian świadomości literackiej felietony satyryczne. 
„Zielonego Balonika” i „Momusa”"1) przekuła w regularne wzorce polskiej kultury, posiadające swą odmianę masową. To wokół nich rozwinął się przecież istotny nurt życia literacko-artystycznego lat 1918-1939 i nowy, popularny obieg kultury - $\mathrm{z}$ kabaretomanią na czele, rozwojem czasopiśmiennictwa satyrycznego i humorystycznego oraz karierą komedii i farsy teatralnej w tle, a następnie $\mathrm{z}$ falą popularności komedii filmowej w latach 30 . Dopełniał go model popularno-autonomicznej literatury ludycznej, przede wszystkim w wydaniu skamandrytów ${ }^{12}$, których część szlifowała przecież pióra jeszcze przed powstaniem „Picadora”, zasilając swoimi utworami czasopisma satyryczne oraz repertuary teatrów kabaretowo-rewiowych okresu wojny: „Miraży”, „Sfinksów” i „Czarnych Kotów”, pierwszych „przybytków podkasanej muzy" dostępnych szerokiemu kręgowi odbiorców od 1915 roku.

Proponuję spojrzenie na ten fenomen oczami jego obserwatorów, sądzę bowiem, że pozwala ono najlepiej wydobyć oraz zrozumieć sprawczy i krytyczny potencjał warszawskiego kabaretu okresu wojny. Sposób bowiem, w jaki wyartykułowany jest sprzeciw wobec tych zjawisk, oraz charakter argumentów, które za nim stoją, pozwala zobaczyć to, co nowe, na tle tego, co zastane, a więc lepiej rozumieć obydwa - zarówno reguły polskiej komunikacji symbolicznej w procesie ich przemian (tych zachodzących i tych prognozowanych), jak i ich społeczno-polityczny kontekst, który pod wpływem owych przemian również ulegał przeobrażeniu. To podczas wojny teatr kabaretowo-rewiowy utorował sobie drogę z peryferiów oficjalnej kultury narodowej w okolice bliskie jej centrum. Coś istotnego musiało się wydarzyć pomiędzy elitarnymi „gestami śmiechu” młodopolan z lat 1910-1914 a Pierwsza szopka warszawską, zainscenizowaną przez pikadorejczyków w 1922 roku w Belwederze dla Rady Ministrów; coś, co sprawiło, że mogło w ogóle dojść do tego wydarzenia; więcej - że odbyło się ono z inicjatywy

${ }^{11}$ Zob. H. Karwacka, Warszawski Kabaret Literacko-Artystyczny „Momus”, Warszawa 1982.

12 Pisanej i publikowanej, o czym warto pamiętać, jeszcze u schyłku wojny, jak np. Wiosna. Dytyramb Tuwima, i wówczas wzbudzającej opór krytyków, nawet przewyższający skalą opisywaną tu kabaretomanię. 
samego Józefa Piłsudskiego, najważniejszej osoby w nowo wskrzeszonym państwie ${ }^{13}$.

Wejście teatru „drugiego nurtu” na salony wiązało się z uznaniem, że śmiech pełnić może faktyczną istotną funkcję społeczną. Świadom był tego Stanisław Brzozowski ${ }^{14}$. Podobne stanowisko wyrażał w 1915 roku Leo Belmont, literat i felietonista demokratycznej „Nowej Gazety”. Uznał on śmiech - a pisał przede wszystkim o satyrze politycznej - za niezbędną praktykę życia społecznego, która pozwala naruszyć „zmurszałe nawyki myśli narodowej"15. Jeśli naród nie uruchamia żywiołu satyrycznego, oznacza to, że „jest skrzywiony przez niewolę"16. Umiejętność śmiania się z siebie i z prześladowców jest według publicysty znamieniem dystansu i samoświadomości właściwym dla wspólnot „zdrowych”, dojrzałych; pełni również do pewnego stopnia funkcję regulacyjną, broni przed autostereotypem i stereotypem, uniemożliwia osunięcie w samozachwyt, ale i resentyment, a także utratę czujności i trzeźwego oglądu rzeczywistości - jest więc ostatecznie remedium na bolączki polskiego życia zbiorowego, diagnozowane w wojennej publicystyce między innymi przez Stefana Żeromskiego i Zygmunta Wasilewskiego, takie jak: literaturocentryzm w wydaniu romantycznym (i szerzej - estetyzację życia) i jego konsekwencje (histrionizm, paseizm,

13 Zob. A. Słonimski, Belweder, [w:] idem, Alfabet wspomnień, wyd. 2 uzup., Warszawa 1989, s. 24-25. Trzeba pamiętać, że już wieczór otwarcia „Pod Picadorem” - 29 listopada 1918 roku - zgromadził elitę ówczesnej Warszawy, również przedstawicieli świata polityki. Antoni Słonimski w wywiadzie udzielonym w 1970 roku polskiej sekcji BBC wspominał, że to felieton humorystyczny i żart przyciągał publiczność do „Picadora”, może nawet dużo bardziej niż sama poezja; mc, Literat. Jak Antoni Słonimski zaraził się poezją, 15.11.2019, PolskieRadio24. pl, https://www.polskieradio24.pl/39/156/Artykul/2404087,Literat-Jak-AntoniSlonimski-zarazil-sie-poezja [dostęp 1.01.2020].

14 Zob. R. Nycz, Gest śmiechu..., op. cit., s. 239-240; zob. też: W. Szulik, Z ducha komizmu. Teoria śmiechu Stanisława Brzozowskiego, „Pamiętnik Literacki” 2018, z. 3, s. 5-23.

15 L. Belmont, Komunikaty felietonisty (58. Ostatni akord), „Nowa Gazeta”, 5 listopada 1915, s. 2.

16 Ibidem. 
eskapizm, apolityczność), retrospektywizm, idolatrię, polonizm ${ }^{17}$, polonocentryzm itp.

Częstsze jednak, choć wciąż nieliczne (trzeba pamiętać, że kabaret do pewnego momentu w zasadzie w dyskursie publicznym nie istniał poza przestrzenią reklamową w prasie, funkcjonował więc jedynie na rynku komercyjnym jako towar, którego obecność nie wymagała komentarza ${ }^{18}$ ) były negatywne głosy krytyków, skłonnych wyrokować, w jakich okolicznościach i z czego wolno się Polakowi podczas wojny śmiać. Pytanie Struga pozostawało aktualne także w wojennych warunkach - w latach 1914-1918 scenariusze wojennej komunikacji medialnej zdominowane były przez tradycyjne tematy i schematy polskiego dyskursu niepodległościowego (pod tym względem I wojna była bowiem kolejną polską irredentą), a częściowo również zaprzęgnięte w tryby prac propagandowych. W związku z tym „oficjalna kultura wojenna” (pojęcie stosowane przez antropologów wojny $^{19}$ ) miała w Polsce lat 1914-1918 barwę Legionów Piłsudskiego i tonację tragiczno-patetyczno-heroiczną. „Krotochwilizm” Polaków widziany w tym kontekście przekraczał granice estetyczne - według jego krytyków, strażników społecznej normy ${ }^{20}$, był niestosownym „odchyleniem” od wojennej

17 Pojęcie to przywołuję za Marią Janion - odnosi się ono do parareligijnego, wręcz sekciarskiego, zrytualizowanego i ekstremistycznego rysu polskiego patriotyzmu o romantycznej genezie; zob. M. Janion, Conrad wobec dylematu polskiego romantyzmu, [w:] eadem, Projekt krytyki fantazmatycznej. Szkice o egzystencjach ludzi i duchów, Warszawa 1991, s. 136-137.

18 Kazimierz Wroczyński w 1916 roku dzielił sceny warszawskie na „przybytki kultury” i „miejsca rozrywki”, które tworzą „kategorię niezwykle szeroką o rozciągłej skali poziomu od scen dramatycznych począwszy - do przytulisk najlżejszej muzy, lokalów z teatrem tylko wspólne miano mających”; K. Wroczyński, Teatr stolicy, „Widnokrąg” 1916, nr 3-4, s. 9.

19 Zob. E. Olzacka, Wojna a kultura. Nowożytna rewolucja militarna w Europie Zachodniej i Rosji, Kraków [cop. 2016], s. 60.

20 Bolesław Leśmian w jednym $\mathrm{z}$ wojennych felietonów pisał o dziennikarzach i redaktorach, że na mocy uzurpowanego sobie prawa do bycia głosem opinii, w imię „spokoju” oraz „dobra ogółu”, stają się reżyserami i strażnikami niesformułowanych, ale przyjętych za oczywiste przekonań, wiedzy intuicyjnej, najczęściej dziedziczonej, zinternalizowanej i znaturalizowanej, reprodukowanej bezrefleksyjnie i nieświadomej własnej „konstruowalności” (co Pierre Bourdieu 
„formy”21. Tylko niektórzy publicyści byli skłonni publicznie przyznawać, że obok oficjalnego dyskursu na czas wojny "przybytki podkasanej muzy” zaczęły odgrywać istotną rolę pośród codziennych aktywności kulturalnych mieszkańców Warszawy ${ }^{22}$. Warto przyjrzeć się dokładniej artykułowi Władysława Rabskiego ${ }^{23}$, ponieważ pozwala on zaobserwować, jak

określił później jako doxa). Dziennikarze są więc w tym kontekście ortodoksami strażnikami dyskursywnych reguł panujących w całym polu społecznym. O tyle, o ile oczywiście są one zgodne z ich własnym interesem; B. Leśmian, Spowiedź dziennikarza, [w:] idem, Szkice literackie, zebrał i oprac. J. Trznadel, Warszawa 2011, s. 105; pierwodruk: Felicjan Kostrzycki [Bolesław Leśmian], Spowiedź dziennikarza, „Myśl Polska” 1915, z. 1, s. 140-146; zob. P. Bourdieu, Dystynkcja. Społeczna krytyka władzy sadzenia, tłum. P. Bilos, Warszawa 2005, s. 526; C. Deer, Doxa, [w:] Pierre Bourdieu: Key Concepts, ed. M. Grenfell, Durham 2008, s. 119-130. W kontekście moich rozważań nad recepcją fenomenu wojennego kabaretu jest to o tyle ważne, że taka pozycja publicystów (Rabski i Nowaczyński) pozwala im wyznaczać również standardy komunikacji humorystycznej - w tym sensie czuwają oni na straży tego, by śmiech nie wyszedł poza dopuszczalne ramy i poza bezpieczną - z punktu widzenia gęsto utkanej sieci strukturalnie zależnych pozycji społecznych - funkcję kompensacyjną.

${ }_{21}$ Zob. M. Janion, Wojna i forma, [w:] eadem, Płacz Generała. Eseje o wojnie, Warszawa [cop. 2007], s. 25-139.

22 Bruno Winawer pisał: „Przed wojną każdy tuzinkowy polityk kawiarniany wyobrażał sobie wcale trafnie jej grozę: huk armat, Dantejskie piekło, ogień huraganowy, aeroplany, bomby... Na tyle fantazji stać było nas wszystkich. Ale kogoś, kto by nam ongi - dwa lata temu - powiedział, że tę drugą rocznicę katastrofy dziejowej obchodzić będziemy u Loursa, w kinematografie, w teatrze na »Eskapadzie« czy "Hiszpańskiej musze" [komedia i farsa grane w warszawskich teatrach w czasie wojny - J.N.], kogoś, kto by nam w żywe oczy śmiał twierdzić, że będziemy tego dnia w kabarecie podśpiewywali Nelsona, w cukierni grali w szachy, w domu zastanawiali się głęboko nad kwestią, czy Krowientyńska powinna jeszcze grywać rolę podlotków - owego kogoś zamknęlibyśmy na pewno w szpitalu wariatów"; B. Winawer, Z dnia na dzień. 28 lipca, „Widnokrąg” 1916, nr 8, s. 8.

${ }^{23}$ Krytyczno-teatralne kompetencje Rabskiego były przedmiotem drwiny w „Sowizdrzale” (obok innych osób decydujących w drugiej połowie 1915 roku o sprawach teatru); Ego, Interview z Kazimierzem Pierwszym, „Sowizdrzał. Satyryczny Tygodnik Ilustrowany" 1915, nr 3, s. 4. 
interpretowano zagrożenia związane z rozwojem teatrów „drugiego nurtu”, zwłaszcza te, które najbardziej utrudniały im wejście do oficjalnej kultury.

„[W] huku dział i łunie pożarów, w chwili najtragiczniejszej i najpoważniejszej, jaką Polska od czasu rozbiorów przeżywa, [...] nie wolno z jej pożogi urządzać iluminacji dla szopek farsowych" ${ }^{24}$ - pisał Rabski. Tymczasem, jak obserwował, krotochwilizm nie ulega presji stosowności (a nawet apodyktycznej sile orzeczenia modalnego nadawcy i jego dyscyplinującego tonu) i nie boi się sięgać nawet po repertuar patriotycznych tematów. „Mówią - pisał dalej - że dla równowagi ducha potrzebna jest godzina karnawału po długich dniach trwogi, niepokojów, denerwujących dyskusji i bieganiny za chlebem" 25 . Prawidłowo, bo w duchu karnawału, krytyk zidentyfikował więc pochodzenie kabaretu i farsy, a także ich funkcję jako widowiska, ale potraktował je wyłącznie jako doraźną, niestosowną formę adaptacji do wojennych warunków, oznakę niedojrzałości Polaków, a nie istotną czynność rytualną o pochodzeniu ludowym ${ }^{26}$. Było to według niego zjawisko niepokojące, ponieważ nie mieściło się w tradycyjnym wyobrażeniu komunikacji kulturowej, w której treść odpowiadała określonej grupie społecznej i modelowi odbioru kultury, jaki ta grupa wytworzyła. Obserwowana przez niego nowa publiczność wymykała się schematom tradycyjnych podziałów społecznych, zwłaszcza kryteriom mieszczańskiej i inteligenckiej konsumpcji kulturowej ${ }^{27}$. Ponieważ w uczestnikach tych widowisk był w stanie dostrzec tylko tłum, mógł mieć poczucie zachwiania społecznego ładu. Nie potrafił go zrozumieć, ponieważ nawet nie chciał go widzieć - zaobserwowany w kabarecie, zaskoczył go i przeraził swoją rzekomą ekspansywnością, przekroczeniem nieprzekraczalnych dotąd granic społecznych. José Ortega y Gasset w klasycznym opracowaniu tego zagadnienia z 1929 roku pisał, również z pewnym niepokojem - wszak opisywał

${ }^{24}$ W. Rabski, Śmiech bezduszny, „Tygodnik Ilustrowany” 1915, nr 10, s. 2.

25 Ibidem.

26 Zob. D. Ratajczakowa, Farsa i wspólnota śmiechu, [w:] eadem, Galeria gatunków widowiskowych, teatralnych i dramatycznych, Poznań 2015, s. 193-201.

27 Dlatego Rabski narzekał na brak w Polsce tradycji mieszczańskiej farsy, mogącej zaspokoić apetyty zgodne z potrzebami tej klasy społecznej, w przeciwieństwie do wyraźnie klasowo ustabilizowanej Francji i jej ambitnej farsy, bardziej zrygoryzowanej pod względem literackim. 
go z perspektywy wykształconego mieszczanina, arystokraty ducha - że na początku XX wieku:

Tłum stał się nagle widoczny, zajął w społeczeństwie miejsce uprzywilejowane. Przedtem, jeżeli nawet istniał, to pozostawał niezauważony, był gdzieś w tle społecznej sceny; teraz wysunął się na sam środek, stał się główną postacią sztuki. Nie ma już bohaterów, jest tylko chór ${ }^{28}$.

Rabski, ale też wielu innych krytyków piszących o wojennej karierze form lekkich, interpretował to zjawisko jako przejaw kryzysu mającego również swoje oblicze społeczno-polityczne: oto na horyzoncie ich postrzegania pojawiła się nowa jakość społeczna - tłum ${ }^{29}$. Ten, łakomy „krotochwilnych” rozrywek, stał się bowiem „widzialny”, to znaczy „postrzegalny” - w sensie, w jakim używa tej kategorii Jacques Rancière ${ }^{30}$. Adolf Nowaczyński z kolei pisał w podobnym tonie o „ścisku” i „zaduchu” panującym w tych przybytkach, co można również odnieść do kategorii „postrzegalności”31. Tłum pojawił się przestrzeniach publicznych (instytucjach wciąż nazywanych teatrami), które dotąd były zarezerwowane dla kogoś innego ${ }^{32}$. Można przyjąć, że pod płaszczykiem świętego oburzenia Rabskiego kryje się lęk związany z politycznymi konsekwencjami obserwowanej zmiany - przed koniecznością nowego „podzielenia postrzegalnego”, to znaczy rekonfiguracją przestrzeni społecznej. Tłum bowiem, jak się wydaje, odnosi się do

28 J. Ortega y Gasset, Bunt mas, tłum. P. Niklewicz, Warszawa 1997, s. 10.

29 Tłum jako nowa i ambiwalentna jakość był już przedmiotem rozpoznań i kulturowych diagnoz zarówno w socjologii i psychologii (G. Tarde, G. Le Bon), jak i w literaturze (np. Ch. Baudelaire, C.K. Norwid). Tutaj pojawia się on w nowym kontekście.

30 J. Rancière, Dzielenie postrzegalnego. Estetyka i polityka, tłum. M. Kropiwnicki i J. Sowa, wstęp M. Pustoła, Kraków 2007.

${ }^{31}$ Jan Sowa wyjaśnia, że „postrzegalność” w terminologii Rancière’a odnosi się ogólnie do poznania zmysłowego; J. Sowa, Od tłumacza, [w:] J. Rancière, op. cit., s. $60-61$.

32 Polegałoby to mniej więcej na tym, że w określonej pod względem parametrów estetycznych czasoprzestrzeni - w tym przypadku teatrze - jesteśmy w stanie pomyśleć tylko takie obiekty (ludzi, przedmioty), które są zgodnie z obowiązującymi tam parametrami estetycznymi. Inne obiekty - „niespójne estetycznie” - są $\mathrm{w}$ praktyce postrzeżeniowej usuwane poza ramy tego subuniwersum. 
grupy szerszej niż dotychczasowe mieszczaństwo: mieści się tu zarówno inteligencja, jak i kołtuneria oraz filisteria. W kabaretowym widowisku nie tylko dotychczasowy przeciwnik artysty - filister - stał się pełnoprawnym widzem i zarazem współuczestnikiem zabawy. Za nim, właśnie podczas wojny, w przestrzeń ogólnonarodowej konsumpcji kulturowej weszła pensjonarka, służąca, drobny paskarz i nowobogacki spekulant, których wspominał najpierw entuzjasta, potem jeden z najznakomitszych artystów kabaretowych, Ludwik Sempoliński:

Życie się jako tako ustabilizowało. Było jednak bardzo ciężko. Koszmarem był panujący głód. Niemcy rekwirowali żywność dla armii, a cywilom wydawali namiastki na kartki. Ludzie nie dojadali i aby oszukać głód, częściej chodzili do teatrów, zwłaszcza na widowiska rozrywkowe. Również dorobkiewicze, żerujący na nędzy i wykorzystujący sytuację, krótko mówiąc: paskarze z wypchanymi portfelami, bawili się na swój sposób i uczęszczali do teatrów rozrywkowych, ponieważ im to imponowało. Stąd duże możliwości dla podkasanych muz, a kierownicy i dyrektorzy tych teatrzyków starali się te sprzyjające okoliczności wykorzystać ${ }^{33}$.

Sempoliński w pewnym stopniu wyjaśnia, jak stan wojennej anomii zaburzenia ładu społecznego i aksjonormatywnego pod wpływem realiów wojny, dla warszawiaków pod pewnymi względami szczególnie dotkliwymi - stworzył sytuację, w której kabaret stawał się istotnym elementem życia kulturalnego, zjawiskiem zarazem komercyjnym i demokratycznym. Nie

${ }^{33}$ L. Sempoliński, Wielcy artyści małych scen, Warszawa 1977, s. 125. Na temat wojennej codzienności znakomite humorystyczne felietony pisał Włodzimierz Perzyński dla tygodnika „Świat”, pokazując przede wszystkim obyczaje filistrów, odbijające się w krzywym zwierciadle wojny, która pozwalała ujrzeć mieszczańską kulturę jako wyzutą z sensu i pogrążoną w kryzysie. Zob. A. Chwalba, Codzienność, [w:] idem, Wielka Wojna Polaków 1914-1918, Warszawa 2018, s. 383-418; Chigi [właśc. K. Wroczyński], Raptularzyk teatralny, „Sowizdrzał. Satyryczny Tygodnik Ilustrowany" 1915, nr 13, s. 8; D. Ratajczakowa, Kabaret, [w:] eadem, Galeria gatunków..., op. cit., s. 205. Na temat ludowo-jarmarcznych powinowactw kabaretu zob. I. Kiec, Wielka Reforma Teatru w świecie karnawału. Coś jednocześnie mądre i śmieszne, [w:] eadem, Wyprzedaż teatru w ręce błazna i arlekina... czyli o kabarecie, Poznań 2001, s. 54-63. 
zrozumiemy jednak tego fenomenu i niechęci, jaką mógł wzbudzać, bez zbadania, co doprowadziło do regularnego gromadzenia się tej „masy” właśnie w kabarecie. Postrzeganie kabaretu jedynie w kategoriach rozrywki kompensującej trudy życia codziennego, jak chciał ją widzieć m.in. Nowaczyński ${ }^{34}$, nie wyjaśnia chociażby jego szerokiej popularności powojennej. Cóż mogło bowiem tak imponować dorobkiewiczom, jakie siły gromadziły zróżnicowany pod względem społecznym miejski tłum w „przybytkach podkasanej muzy”, że zabierały one „normalnym” teatrom widzów (na co zresztą też narzekał autor Małpiego zwierciadła ${ }^{35}$ ) i czyniły z niego najbardziej demokratyczną i najdostępniejszą instytucję polskiej kultury miejskiej?

Ze wspomnień Kazimierza Wroczyńskiego wynika, że od początku działalności „Mirażu”, „Sfinksa” i „Czarnego Kota” jego kierownicy artystyczni (zwłaszcza Jan Boczkowski i sam Wroczyński) starali się zapewnić poziom przedstawień, który byłby atrakcyjny dla jak najszerszego grona odbiorców (a więc i spełniał podstawowe kryterium masowości kultury ${ }^{36}$ ). To miało zapewnić sukces kasowy (warszawskie teatry wojenne, nie tylko kabaretowe, działały w warunkach całkowitej komercjalizacji), a zatem i przetrwanie (kierownikowi „Czarnego Kota” wkrótce nawet „pensję dyrektora fabryki" ${ }^{37}$ ). Wroczyński był świadom, że trzeba stworzyć nową jakość artystyczną ${ }^{38}$, która zarówno zaspokoi potrzeby inteligencji (nieprzyzwyczajonej do śmiechu, niechętnej tej formie sztuki ${ }^{39}$ ), jak i dotrze do nowego

34 A. Nowaczyński, Rozmirażowanie, „Teatr. Wydawnictwo Teatru Polskiego w Warszawie" 1918/1919, z. 2, s. 31.

35 Ibidem.

36 Zob. A. Kłoskowska, Kultura masowa, Warszawa 2005, s. 287-288.

37 K. Wroczyński, „Czarny Kot”, [w:] idem, Pół wieku wspomnień teatralnych, Warszawa 1957, s. 139.

${ }^{38}$ W 1915 roku w „Sowizdrzale” zdawał sprawę z tego, ile energii włożyło środowisko twórców „w wykoncypowanie rozmaitego rodzaju odmian tanglowych”, żeby stworzyć idealny wynalazek dla Warszawy; Chigi [właśc. K. Wroczyński], op. cit., s. 8.

39 Nad powodami takiego stanu rzeczy należałoby się dokładniej zastanowić, na co nie ma tutaj miejsca. Mogło to wynikać z faktu, że kapitał kulturowy inteligencji, która sprawowała hegemonią kulturową, był tradycyjnie transmitowany za pomocą jednego tylko, elitarnego kanału, funkcjonującego w dwóch odmianach autonomicznej i zaangażowanej, między którymi granicę wytyczono w zasadzie 
odbiorcy - tego, dla którego dotąd nie było miejsca w teatrze pierwszego nurtu. Wymagało to udanego połączenia rozrywki i sztuki oraz wynikało z założenia - które wcale nie było oczywiste w ówczesnej świadomości społecznej - że nie ma sprzeczności między wypełnianiem poważnych zadań teatru a zabawą ${ }^{40}$. Tymczasem popularny obieg kultury postrzegano jako zagrożenie dla realizacji poważnych zadań instytucji kultury, które w XIX wieku pełniły często role zastępcze wobec nieistniejących instytucji państwowych (w prasie znajdziemy wiele takich wypowiedzi) ${ }^{41}$. Teatr rozrywkowy miał być - w oczach niektórych krytyków - nie tyle odpowiedzią na nowe potrzeby odbiorców, ile raczej przejawem komercjalizacji kultury, będącej wynikiem przejęcia jej instytucji przez nowych „graczy”, nastawionych wyłącznie na zysk ${ }^{42}$. Taka ocena sytuacji przyczyniła się do pogłębiania rozwarstwień obiegów polskiej kultury, a w dłuższej perspektywie wywarła istotny wpływ na ukształtowanie kilku odrębnych modelów literatury właściwych dla polskiego modernizmu po 1918 roku $^{43}$.

W takiej sytuacji Wroczyński oraz inni kierownicy i dyrektorzy artystyczni teatrów szukali sposobów na stworzenie nowej jakości rozrywki, która zaspokoiłaby potrzeby możliwie szerokiej publiczności - i tej starej, i tej nowej. Według dyrektora „Czarnego Kota” taką nową jakość byli w stanie stworzyć pisarze - największą nadzieję pokładał właśnie w najmłodszym

dopiero podczas młodopolskich sporów o sztukę. W kanale tym śmiech był, jak wskazałam, rzeczą stosunkowo nową, to po pierwsze; po drugie - niełatwo dawał się pogodzić z funkcjami, które zwyczajowo przypisywano sztuce w narodzie nieposiadającym państwa.

40 K. Wroczyński, „Czarny Kot”..., op. cit., s. 138.

${ }^{41}$ Zob. np. B. Hertz, Siły ukryte, „Widnokrąg” 1916, nr 9-10, s. 7.

42 Trudno odmówić tym przewidywaniom słuszności, można jednak się zastanawiać nad tonem, w jakim wypowiadane były te skargi. Sam Wroczyński zaznaczał w kilku miejscach, że jego teatr funkcjonował na prawach rynkowych Wroczyński był w nim dyrektorem artystycznym, a jego przełożeni finansowi niewiele w jego mniemaniu wiedzieli o sztuce, ponieważ niespecjalnie interesowała ich jakość przygotowywanych przez jego zespół przedstawień. Trzeba jednak pamiętać, że warszawskie teatry funkcjonowały podczas wojny bez jakiegokolwiek wsparcia finansowego ze strony miasta.

${ }^{43}$ Zob. R. Nycz, Literatura nowoczesna: cztery dyskursy, [w:] idem, Poetyka doświadczenia. Teoria - nowoczesność - literatura, Warszawa 2012, s. 192-194. 
pokoleniu, z jego „herostratesową” energią i brakiem klasowych uprzedzeń ${ }^{44}$. Gwarantowana przez pisarzy (m.in. Tuwima i Słonimskiego, potem Brzechwę) „literackość” całego przedsięwzięcia zapewniała mu inteligencki polor - kusiła obietnicą awansu tych, którzy nie brali dotychczas udziału w ogólnonarodowym obiegu kultury. Na tym polegała atrakcyjność tego teatru dla nowych grup odbiorczych, o czym pisał Sempoliński.

Ważną rolę w budowaniu nowej kabaretowej publiczności odegrała również polityczna aktualność przedstawień, która była bodaj najbardziej charakterystyczną cechą wojennych programów teatrów tego nurtu. Ludzie podczas wojny byli głodni nie tylko rozrywki, ale również informacji i komentarza politycznego ${ }^{45}$. Zaspokojenie tej potrzeby należało do jednego z podstawowych zadań scen kabaretowych ${ }^{46}$. Dzięki pewnemu stopniowi upolitycznienia "przybytki podkasanej muzy” stawały się przestrzenią edukacji polityczno-obywatelskiej tej nowej publiczności. Było to możliwe dzięki temu, że kabaret jest - jak piszą teoretycy tej formy sztuki - „gra z zastanymi zależnościami w systemie wiedzy, systemu nawyków, stereotypów kognitywnych publiczności, a z drugiej strony - gra destruktywną" ${ }^{\text {"77 }}$. W myśl tej teorii kabaret „nie proponuje rozwiązań (jak np. literatura), nie projektuje modeli opisu świata, lecz burzy te zastane ${ }^{\prime 38}$. Sytuację była w stanie wyjaśnić już ówczesna socjologia. Widowisko kabaretowe, będąc - według Georga Simmela - jedną z „zabawowych form uspołecznienia”, wytwarzało warunki do konstruowania nowych doświadczeń wspólnotowych opartych na równości ${ }^{49}$. Kabaret był enklawą autonomicznej zabawy, wolnej od ograniczeń instytucjonalnych i rygorów życia społecznego. Można więc widzieć wojenną karierę „małych form” nie tylko w kontekście kompensacyjnym, ale również jako przestrzeń, w której realizowano nowe społeczne potrzeby, demokratyzującą kulturę polską, wytwarzającą nową, zróżnicowaną - częściowo już

44 K. Wroczyński, Kabaret..., op. cit., s. 205.

${ }_{45}$ M. Fleischer, Zarys teorii kabaretu, [w:] idem, Konstrukcja rzeczywistości, Wrocław 2002, s. 303.

46 W. Borodziej, M. Górny, Głód informacji, [w:] eidem, Nasza wojna, t. 1: Imperia. 1913-1916, Warszawa [cop. 2014], s. 245-268.

${ }_{47}$ M. Fleischer, op. cit., s. 303 (kursywa oryginalna).

48 Ibidem.

49 G. Simmel, Socjologia, tłum. M. Łukasiewicz, Warszawa 2005, s. 34-42. 
umasowioną - publiczność. Można ją za Kazimierzem Żygulskim nazwać „wspólnotą śmiechu”, będącą rodzajem wspólnoty kulturowej połączonej szczególną więzią społeczną, zawiązywaną w kabarecie za pomocą właściwych dlań, opartych na śmiechu form uspołecznienia ${ }^{50}$. Morfologiczną cechą kabaretu jest bowiem interakcyjność między kabaretystami: aktorami, konferansjerami i poetami a widzami ${ }^{51}$, efektywnie spełniająca funkcję integracyjną i identyfikacyjną. Warszawskie kabarety musiały tę funkcję realizować należycie, skoro w każdym roku wojny powstawały i utrzymywały się w mieście nowe sceny kabaretowo-rewiowe. Dzięki nim rozszerzył się krąg publiczności teatralnej i doszło do wytworzenia nowych form uczestnictwa w kulturze oraz istotnych podwalin kultury popularnej, która stopniowo autonomizowała się wobec istniejących struktur społecznych. Nowa „wspólnota” - cały legion „bękartów rampy i kulis”" ${ }^{2}$ oraz uczestników widowisk - nie była już tak sztywno związana z dotychczasową strukturą; można wręcz założyć, że ją częściowo rozluźniała i zacierała dawniejsze, wyrazistsze granice tegoż uczestnictwa ${ }^{53}$. Stefan Żółkiewski uznał niegdyś to zjawisko za jedną z dwóch najważniejszych tendencji rozwojowych kultury przełomu XIX i XX wieku na ziemiach polskich ${ }^{54}$.

50 K. Żygulski, op. cit., s. 19.

51 Teoretycy kabaretu zwracają uwagę na fakt, że specyficzną cechą tej formy widowiska jest jego interakcyjność: „gra się do publiczności”, kabaretysta musi współpracować z publicznością (M. Fleischer, op. cit., s. 305). Dobrochna Ratajczakowa (op. cit., s. 204) pisała wręcz o familiarnym, ludyczno-wspólnotowym typie komunikacji kabaretowej.

52 Chigi [właśc. K. Wroczyński], op. cit., s. 8.

53 O właściwej dla kabaretu płynności, jeśli chodzi o przynależność do konkretnego obiegu, pisała D. Ratajczakowa (op. cit., s. 205), wskazując, że w tej formie sztuki granice między obiegiem trywialnym a elitarnym były płynne.

54 S. Żółkiewski, Społeczne konteksty kultury literackiej na ziemiach polskich (1890-1939), przyg. do druku A. Brodzka, O.S. Czarnik, M. Hopfinger, Warszawa 1995, s. 8-9. W efekcie, z jednej strony, coraz większe grupy miały dostęp do pewnych form kultury wysokiej (w jej wersji ludycznej) i brały udział w formującej się kulturze ogólnonarodowej. Z drugiej - instytucje kultury, które posiadały tradycję i legitymację „sztuki wysokiej”, w wojennej Warszawie zyskały nowy status i zasięg społeczny, stając się stopniowo instytucjami o charakterze masowym. 
Dopiero gdy dostrzeżemy te cechy wojennej kabaretomanii, staje się zrozumiałe, co najbardziej niepokoiło Rabskiego w zaobserwowanym nowym zjawisku. Można uznać, że jego krytyka była przejawem oporu lub formą buntu wobec procesów dyferencjacji obiegów sztuki i stojącej za nimi istotnej kulturowej i politycznej zmiany. Oto w przestrzeni społecznej pojawił się nowy gracz, który urościł sobie prawo bytu, wykorzystując sprzyjającą koniunkturę. Był on, jak zauważa z kolei Nowaczyński, nie tylko widoczny, przez co milcząco domagał się uznania, ale ujawnił już swą sprawczą moc„urobił” instytucje sztuki (pisanej przez krytyka ironicznie przez duże „S”) tak, że stały się one „przybytkami Sztuki stosowanej konsekwentnie do poziomu konsumentów" 55 .

Obserwacje przywołanych krytyków dotyczą jakości nowych form kultury popularnej, ale przede wszystkim procesów umasowienia kultury, na które patrzyli oni z perspektywy schyłku tego, co Peter Sloterdijk nazwał „epoką idealistycznej protekcyjności”56, w której inteligent w roli hegemona $^{57}$ roztaczał opiekę nad niższymi warstwami społecznymi, nie dopuszczając do siebie myśli, że te, skrystalizowane jako masa, mogłyby się stać podmiotem obdarzonym mocą sprawstwa. Znamienne jest tu zwłaszcza konserwatywne stanowisko Rabskiego - jego niepokój wynika z dbałości o ład i stałość struktury społecznej, które zabawa i śmiech mogłyby naruszyć dzięki swemu pozasystemowemu charakterowi, a przede wszystkim marginalnej pozycji.

Śmiech bowiem bierze się z zaburzenia normy, które może przynosić chwilową radość. Zaburzenie to może, lecz nie musi pociągać za sobą zmiany. Jak zauważał już Henri Bergson, ale i Jan Stanisław Bystroń, śmiech może wywoływać społeczne zmiany ${ }^{58}$, zwłaszcza w sytuacji zachwiania istnieją-

55 A. Nowaczyński, op. cit., s. 31.

56 P. Sloterdijk, Pogarda mas. Szkic o walkach kulturowych we współczesnym społeczeństwie, tłum. B. Baran, Warszawa 2003, s. 7.

${ }^{57} \mathrm{Na}$ temat dominacji tej warstwy społecznej zob. m.in. R. Smoczyński, T. Zarycki, Totem inteligencki. Arystokracja, szlachta i ziemiaństwo w polskiej przestrzeni społecznej, Warszawa 2017, s. 23-27; Dzieje inteligencji polskiej do roku 1918, t. 1-3, red. J. Jedlicki, Warszawa 2008.

${ }_{58}$ H. Bergson, Śmiech. Esej o komizmie, tłum. S. Cichowicz, Kraków 1977, s. 51-52; J.S. Bystroń, Komizm, Lwów - Warszawa [cop. 1939]. Zob. też: J. Porazinski, 
cego ładu i związanej z tym anomii (w jej stan wprowadziła warszawiaków wojna, okupacja niemiecka, polityczna niewiadoma, brak politycznego konsensusu Polaków co do polityki sojuszniczej, problemy aprowizacyjne itd.), ale może też pełnić funkcję stabilizującą i dyscyplinującą ${ }^{59}$.

Według Bohdana Dziemidoka, podobnie jak w przypadku przywoływanego już Żygulskiego ${ }^{60}$, konkretna forma komizmu powiązana jest $\mathrm{z}$ poglądami i cechami grupy społecznej, wokół której powstała i pośród której funkcjonuje. W związku z tym istniejące w społeczeństwie podziały mogą nakładać się na odmienne rozumienie roli i źródeł śmiechu ${ }^{61}$. Manipulowanie "granicami” praktyk związanych ze śmiechem mogło być więc zarówno narzędziem dyskursywnej kontroli i dyscyplinowania (Rabski), jak i transgresji, jak w przypadku wojennego kabaretu. W pewnym sensie kabaret posiada potencjał transgresyjny ze swej istoty, ponieważ - jak pisał jeden z jego teoretyków - „komunikacja w kabarecie nie jest ukierunkowana na określone znaczenia, lecz na ćwiczenie kognitywnych umiejętności, burzenie istniejących związków sensu, podawanie ich w wątpliwość, stawianie pod znakiem zapytania [...] i tematyzowanie komunikacji w trakcie komunikowania"62. To zaś - już według Umberta Eco - jest warunkiem wydobycia krytycznego potencjału śmiechu ${ }^{63}$ : trzeba sprawić, że normy uznane za powszechne i obowiązujące nie będą utrwalone (jak zdaniem Eco dzieje się na ogół w przypadku większości sytuacji komicznych), a stanie się tak wówczas, gdy zostanie obnażona sytuacja dyskursywna, w której normy te się konstytuują. Wtedy stracą one swą oczywistość i bezdyskusyjność.

Staropolska kultura śmiechu. Ludzie - teksty - konteksty, Toruń 2015, s. 14. Na temat śmiechu w perspektywie politologicznej zob. T. Rawski, Śmiech a władza. Przeglad społecznych funkcji komizmu, „Studia Politologiczne” 2016, t. 41, s. 240-258.

59 S. Morawski, Paradoksy filozofii komizmu, [w:] H. Bergson, op. cit., s. 17.

60 Zob. przyp. nr 9.

${ }_{61}$ B. Dziemidok, O komizmie, Warszawa 1967.

${ }^{62}$ M. Fleischer, op. cit., s. 303.

63 U. Eco, Komizm i norma, tłum. J. Ugniewska, [w:] idem, Semiologia życia codziennego, wstęp J. Ugniewska, tłum. J. Ugniewska, P. Salwa, Warszawa 1996, s. 338-339. 
„Młody las" ${ }^{\text {64 }}$ polskich twórców kabaretowych (m.in. Tuwim, Słonimski i Lechoń) podczas wojny obnażał tę sytuację, nie tylko dostarczając kabaretowi wysokiej jakości rozrywkę, ale również - niemal jednocześnie $\mathrm{z}$ tekstami humorystycznymi, całkiem serio, $\mathrm{w}$ natchnieniu ${ }^{65}$ - wykonywał „herostratesowe” gesty poetyckie z lat 1917-1918. Były one komplementarne względem pisanych w tym czasie satyr, które z kolei stanowiły karnawałowe intermedium w trakcie trwania kolejnych polskich „dziadów”, pozwalały na rozbijanie - jak chciał Belmont - „zmurszałych nawyków myśli narodowej" i miały ostatecznie przynieść radosną wolność od, charakterystycznej dla polskiego dziewiętnastowiecza, inteligenckiej „elitarnej moralności obowiązku"66. Kabaret w tym kontekście pozwalał nie tylko przetrwać, ale i rozsadzał samą materię narodowego dyskursu, tworząc przestrzeń ekspresji o charakterze liminalnym ${ }^{67}$, umożliwiającą wytworzenie nowych wzorców zachowań (w tym politycznych i obywatelskich) oraz nowego rodzaju więzi społecznych, które będą współdecydowały o kształcie polskiej kultury dwudziestolecia międzywojennego.

${ }^{64}$ K. Wroczyński, Kabaret..., op. cit., s. 205.

65 Tak Lechoń wspomina pisanie Karmazynowego poematu w wywiadzie dla radia „Wolna Europa” w 1952 roku, dostępnym we fragmentach w Internecie: sm, Jan Lechoń odsłania tajemnice natchnienia, 4.05.2012, PolskieRadio24.pl, https://www. polskieradio24.pl/5/3/Artykul/597557,Jan-Lechon-odslania-tajemnice-natchnienia [dostęp 1.12.2019].

${ }_{66}$ Określenia tego Barthes użył w odniesieniu do francuskiej kultury burżuazyjnej, ale pozwala ono uchwycić też najważniejsze znamię dziewiętnastowiecznego etosu polskiej inteligencji, jaką była konieczność służby na rzecz narodu, która jednocześnie legitymizowała jej pozycję; R. Barthes, Przyjemność tekstu, tłum. A. Lewańska, Warszawa 1997, s. 65-66.

${ }^{67} \mathrm{~W}$ sensie, w jakim kategorią tą posługiwał się m.in. Victor Turner. Według badacza w okresie liminalności ( $w$ tym w stanie kabaretowej zabawy, przyczyniającej się do ukonstytuowania się nowej wspólnoty [communitas]) dochodzi do obnażania wszelkich więzi społecznych za pomocą symboli; struktura społeczna ulega uproszczeniu, symboliczna zaś - wzbogaceniu. V. Turner, Proces rytualny. Struktura $i$ antystruktura, tłum. E. Dżurak, wstęp J. Tokarska-Bakir, Warszawa 2010, s. 169 i passim. 


\section{Bibliografia}

Roland Barthes, Przyjemność tekstu, tłum. A. Lewańska, KR, Warszawa 1997.

Leo Belmont, Komunikaty felietonisty (58. Ostatni akord), „Nowa Gazeta”, 5 listopada 1915.

Henri Bergson, Śmiech. Studium o komizmie, tłum. S. Cichowicz, Wydawnictwo Literackie, Kraków 1977.

Marta Olga Bieńka, Prowizorium wojenne, [w:] eadem, Teatr warszawski 1880-1919, Teatr Narodowy, Warszawa 2015.

Włodzimierz Borodziej, Maciej Górny, Głód informacji, [w:] eidem, Nasza wojna, t. 1: Imperia. 1913-1916, Grupa Wydawnicza Foksal - Wydawnictwo WAB, Warszawa [cop. 2014].

Pierre Bourdieu, Dystynkcja. Społeczna krytyka władzy sądzenia, tłum. P. Bilos, Wydawnictwo Naukowe Scholar, Warszawa 2005.

Jan Stanisław Bystroń, Komizm, Książnica Atlas, Lwów - Warszawa [cop. 1939].

Chigi [właśc. Kazimierz Wroczyński], Raptularzyk teatralny, „Sowizdrzał.

Satyryczny Tygodnik Ilustrowany" 1915, nr 13.

Andrzej Chwalba, Codzienność, [w:] idem, Wielka Wojna Polaków 1914-1918, Wydawnictwo Naukowe PWN, Warszawa 2018.

Cécile Deer, Doxa, [w:] Pierre Bourdieu: Key Concepts, ed. M. Grenfell, Acumen, Durham 2008.

Dzieje inteligencji polskiej do roku 1918, t. 1-3, red. J. Jedlicki, Nertion, Warszawa 2008.

Bohdan Dziemidok, O komizmie, Książka i Wiedza, Warszawa 1967.

Umberto Eco, Komizm i norma, tłum. J. Ugniewska, [w:] idem, Semiologia życia codziennego, wstęp J. Ugniewska, tłum. J. Ugniewska, P. Salwa, Czytelnik, Warszawa 1996.

Ego, Interview $z$ Kazimierzem Pierwszym, „Sowizdrzał. Satyryczny Tygodnik Ilustrowany" 1915, nr 3.

Michael Fleischer, Zarys teorii kabaretu, [w:] idem, Konstrukcja rzeczywistości, Wydawnictwo UWr, Wrocław 2002.

Benedykt Hertz, Siły ukryte, „Widnokrąg” 1916, nr 9-10.

Maria Janion, Conrad wobec dylematu polskiego romantyzmu, [w:] eadem, Projekt krytyki fantazmatycznej. Szkice o egzystencjach ludzi i duchów, PEN, Warszawa 1991.

Maria Janion, Wojna i forma, [w:] eadem, Płacz Generała. Eseje o wojnie, Sic!, Warszawa [cop. 2007]. 
Halina Karwacka, Warszawski Kabaret Literacko-Artystyczny „Momus”, PWN, Warszawa 1982.

Izolda Kiec, Wielka Reforma Teatru w świecie karnawału. Coś jednocześnie mądre i śmieszne, [w:] eadem, Wyprzedaż teatru $w$ ręce błazna $i$ arlekina... czyli o kabarecie, Wydawnictwo Poznańskie, Poznań 2001.

Antonina Kłoskowska, Kultura masowa, Wydawnictwo Naukowe PWN, Warszawa 2005.

Edward Krasiński, Warszawskie sceny 1918-1939, PIW, Warszawa 1976.

Anna Kuligowska-Korzeniewska, Kabaret w „złym mieście” podczas Wielkiej Wojny,

[w:] Kabaret. Poważna sprawa?, red. D. Fox, J. Mikołajczyk, Wydawnictwo UŚ, Katowice 2015.

Bolesław Leśmian, Spowiedź dziennikarza, [w:] idem, Szkice literackie, zebrał i oprac. J. Trznadel, PIW, Warszawa 2011.

Michał Paweł Markowski, Polska literatura nowoczesna. Leśmian - Schulz Witkacy, TAiWPN Universitas, Kraków 2007.

mc, Literat. Jak Antoni Słonimski zaraził się poezja, 15.11.2019, PolskieRadio24.pl, https://www.polskieradio24.pl/39/156/Artykul/2404087,Literat-Jak -Antoni-Slonimski-zarazil-sie-poezja.

Stefan Morawski, Paradoksy filozofii komizmu, [w:] H. Bergson, Śmiech. Esej o komizmie, tłum. S. Cichowicz, Wydawnictwo Literackie, Kraków 1977.

Adolf Nowaczyński, Rozmirażowanie, „Teatr. Wydawnictwo Teatru Polskiego w Warszawie" 1918/1919, z. 2.

Ryszard Nycz, Gest śmiechu. Z przemian świadomości literackiej początku XX wieku (do pierwszej wojny światowej), [w:] idem, Język modernizmu. Prolegomena historycznoliterackie, Wydawnictwo Naukowe UMK, Toruń 2013.

Ryszard Nycz, Literatura nowoczesna: cztery dyskursy, [w:] idem, Poetyka doświadczenia. Teoria - nowoczesność - literatura, IBL PAN, Warszawa 2012.

Elżbieta Olzacka, Wojna a kultura. Nowożytna rewolucja militarna w Europie Zachodniej i Rosji, Wydawnictwo UJ, Kraków [cop. 2016].

José Ortega y Gasset, Bunt mas, tłum. P. Niklewicz, Muza, Warszawa 1997. Jarosław Porazinski, Staropolska kultura śmiechu. Ludzie - teksty - konteksty, Wydawnictwo Naukowe UMK, Toruń 2015.

Władysław Rabski, Śmiech bezduszny, „Tygodnik Ilustrowany” 1915, nr 10.

Jacques Rancière, Dzielenie postrzegalnego. Estetyka i polityka, tłum. M. Kropiwnicki

i J. Sowa, wstęp M. Pustoła, Korporacja Ha!Art, Kraków 2007.

Zbigniew Raszewski, Krótka historia teatru polskiego, PIW, Warszawa 1990. 
Dobrochna Ratajczakowa, Galeria gatunków widowiskowych, teatralnych i dramatycznych, Wydawnictwo Naukowe UAM, Poznań 2015.

Tomasz Rawski, Śmiech a władza. Przeglad społecznych funkcji komizmu, „Studia Politologiczne" 2016, t. 41.

Ludwik Sempoliński, Wielcy artyści małych scen, Czytelnik, Warszawa 1977.

Georg Simmel, Socjologia, tłum. M. Łukasiewicz, Wydawnictwo Naukowe PWN, Warszawa 2005.

Peter Sloterdijk, Pogarda mas. Szkic o walkach kulturowych we współczesnym społeczeństwie, tłum. B. Baran, Spółdzielnia Wydawnicza Czytelnik, Warszawa 2003.

Antoni Słonimski, Belweder, [w:] idem, Alfabet wspomnień, wyd. 2 uzup., PIW, Warszawa 1989.

sm, Jan Lechoń odsłania tajemnice natchnienia, 4.05.2012, PolskieRadio24.pl, https://www.polskieradio24.pl/5/3/Artykul/597557,Jan-Lechon-odslaniatajemnice-natchnienia.

Rafał Smoczyński, Tomasz Zarycki, Totem inteligencki. Arystokracja, szlachta i ziemiaństwo w polskiej przestrzeni społecznej, IFiS PAN, Warszawa 2017.

Andrzej Strug, Zakopanoptikon, czyli kronika czterdziestu dziewięciu dni deszczowych w Zakopanem, Czytelnik, Warszawa 1957.

Weronika Szulik, Z ducha komizmu. Teoria śmiechu Stanisława Brzozowskiego, „Pamiętnik Literacki” 2018, z. 3.

Roman Taborski, Warszawskie teatry prywatne w okresie Młodej Polski. 1905-1918, PWN, Warszawa 1980.

Victor Turner, Proces rytualny. Struktura i antystruktura, tłum. E. Dżurak, wstęp J. Tokarska-Bakir, PIW, Warszawa 2010.

Maciej Urbanowski, Gest śmiechu w literaturze dwudziestolecia międzywojennego (rekonesans), „Wielogłos” 2007, nr 1.

Bruno Winawer, $Z$ dnia na dzień, „Widnokrąg” 1916, nr 8.

Kazimierz Wroczyński, „Czarny Kot”, [w:] idem, Pót wieku wspomnień teatralnych, Czytelnik, Warszawa 1957.

Kazimierz Wroczyński, Kabaret, [w:] Dymek zpapierosa, czyli wspomnienia o scenach, scenkach i nadscenkach, red. K. Rudzki, Iskry, Warszawa 1959.

Kazimierz Wroczyński, Teatr stolicy, „Widnokrąg” 1916, nr 3-4.

Stefan Żółkiewski, Kultura literacka (1918-1932), Zakład Narodowy im. Ossolińskich, Wrocław 1973. 
Stefan Żółkiewski, Społeczne konteksty kultury literackiej na ziemiach polskich (1890-1939), przyg. do druku A. Brodzka, O.S. Czarnik, M. Hopfinger, IBL PAN, Warszawa 1995.

Kazimierz Żygulski, Wspólnota śmiechu. Studium socjologiczne komizmu, PIW, Warszawa 1985.

\section{Is It Allowed to Laugh in Time of War? The Career of the 'Second Current' Theater in Warsaw in the Years 1914-1918 (from the Point of View of Selected Satirists and Literary Critics)}

The article is dedicated to the phenomenon of development of the 'second current' theater (popular and music hall scenes) in the years 1914-1918. Having remained unexplored until now, the phenomenon has been analyzed in view of its perception (statements of literary critics, journalism, memories of authors of cabaret scenes), primarily interpreted against the background of various theories of laugh, comedy and cabaret (Bergson, Eco, Fleischer, Simmel, Żygulski). The main thesis of the article is that cabaret work developed in contrast to official war culture and performed not only the compensatory function, but also guaranteed a cultural promotion for new receivers and created new experience for communities. In this way it contributed to the democratization of culture and enhanced the processes of differentiation of literary circulation. By creating a discursive space of liminal character, it facilitated the emergence of new patterns of behavior (including political and civic ones) as well as new kind of social bonds, characteristic of the Polish culture in the interwar period.

Keywords: World War I, comedy, cabaret, theater, national discourse 